\title{
Purification and Some Properties of Glutamine Synthetases from Bifidobacteria
}

\author{
Masayuki Hatanaka, Takashi TaChIKI, Ryoko FuruKaWA \\ and Tatsurokuro TOCHIKURA \\ Department of Food Science and Technology, Faculty \\ of Agriculture, Kyoto University, Kyoto 606, Japan
}

Received August 13, 1986

\begin{abstract}
Glutamine synthetases [L-glutamate; ammonia ligase (ADP forming), EC 6.3.1.2] were purified, respectively, 570-, 220- and 80-fold with 12,5 and $0.5 \%$ yields from cell-free extracts of Bifidobacterium bifidum a, B. breve 203 and B. pseudolongum a. The purification procedure consisted of cell disruption, ammonium sulfate fractionation and column chromatographies on DEAEcellulose, Sepharose 6B and hydroxylapatite. The purified enzymes were judged to be homogeneous on polyacrylamide disc gel electrophoresis. They had similar molecular weights of about 500,000. The optimum $\mathrm{pH}$ was $6.0 \sim 6.5$ for their biosynthetic reactions with $30 \mathrm{mM} \mathrm{Mg}^{2+}$, and 6.5 for their $\gamma$-glutamylhydroxamate forming (transferring) reactions. The $\mathrm{Km}$ values for L-glutamate, ammonia and ATP in their biosynthetic reactions were, respectively, $18 \sim 25 \mathrm{mM}, 0.56 \sim 0.69 \mathrm{~mm}$ and $1.5 \sim 2.0 \mathrm{~mm}$ with $30 \mathrm{mM} \mathrm{Mg}^{2+}$ as a cofactor. When $7.5 \mathrm{mM} \mathrm{Mn}^{2+}$ was substituted for $30 \mathrm{mM} \mathrm{Mg}^{2+}$, the $K m$ for L-glutamate decreased by $8.6 \sim 23$-fold. The optimum $\mathrm{pH}$ for the biosynthetic reactions and the susceptibility of the enzymes to some metabolites also varied with the kind of divalent cation added.
\end{abstract}

Bifidobacteria, gram-positive anaerobes first isolated from a breast-fed infant by Tisser, ${ }^{1)}$ are the predominant organisms in the intestinal flora of humans and some other animals. ${ }^{2)}$ In contrast with some intestinal bacteria which produce noxious substances for the host, bifidobacteria are supposed to take part in reducing putrefactive bacteria and their toxic metabolites in the intestine. Therefore, the organisms have been used in the treatment and prophylaxis for some deseases in humans and animals. ${ }^{3 \sim 5 \text { ) }}$

We have investigated the enzymatic features of sugar metabolism in bifidobacteria. ${ }^{6 \sim 9)}$ However, there is little information available on their nitrogen metabolism, which might be related to their functions in the intestine. Our previous paper ${ }^{10)}$ on the distribution of glutamine synthetase and glutamate dehydrogenase, which might participate in ammonia assimilation by Bifidobacterium bifidum a, emphasized the need for further characterization of highly purified preparations. The present paper deals with the isolation and properties of glutamine synthetases from $B$. bifidum a (human origin), B. breve 203 (human origin) and $B$. pseudolongum a (pig origin).

Glutamine synthetases [EC 6.3.1.2] have been found and studied in a variety of bacteria,${ }^{11 \sim 18)}$ yeast ${ }^{19)}$ algae, ${ }^{20,21)}$ higher plants ${ }^{22}$ and animals. ${ }^{23,24)}$ Stadtman and Ginsburg ${ }^{25}$ ) and Holzer and Duntz ${ }^{26)}$ concluded that glutamine synthetases are controlled in gramnegative enteric bacteria by the following complex of mechanisms: (1) repression of enzyme synthesis by alteration in the nitrogen supply to the cell, (2) modulation of enzyme activity in response to divalent cations, (3) feedback inhibition by end products, (4) covalent modulation by adenylylation, and (5) energy charge. The properties of the bifidobacterial enzymes were discussed mainly from the standpoints of (2) and (3). 


\section{MATERIALS AND METHODS}

Microorganisms and cultivation. B. bifidum a and $B$. pseudolongum a were kindly supplied by Dr. Mitsuoka (University of Tokyo and The Institute of Physical and Chemical Research). B. breve 203 was isolated from human feces in our laboratory and identified by the method of Mitsuoka. ${ }^{27)}$ A colony of each organism that appeared on a BL-agar plate with the steel wool method ${ }^{27)}$ was inoculated into $5 \mathrm{ml}$ of Briggs Liver broth ${ }^{27)}$ and then incubated at $37^{\circ} \mathrm{C}$ for 3 days according to the same method. The culture was then transferred to $500 \mathrm{ml}$ of the medium described previously ${ }^{10}$ in a $500-\mathrm{ml}$ Sakaguchi flask, followed by incubation for 3 days at $37^{\circ} \mathrm{C}$. The resultant culture was inoculated into 30 liters of the medium in a 30 -liter jar fermentor and then incubated at $37^{\circ} \mathrm{C}$ for 2 days with stirring at $50 \mathrm{rpm}$ under an atmosphere of $\mathrm{CO}_{2}$. The cells were harvested by centrifugation $(10,000 \times g)$ and stored at $-20^{\circ} \mathrm{C}$.

Assay. The enzyme activity was measured in three reactions. (1) Transferring reaction: a mixture $(1.0 \mathrm{ml})$ containing $100 \mathrm{~mm}$ imidazole- $\mathrm{HCl}$ buffer ( $\mathrm{pH} 6.5$ ), $35 \mathrm{~mm}$ L-glutamate, $10 \mathrm{~mm}$ hydroxylamine- $\mathrm{HCl}, 1.0 \mathrm{mM} \mathrm{MnCl}_{2}$, $0.4 \mathrm{~mm}$ ADP, $10 \mathrm{~mm}$ potassium arsenate and $0.05 \sim 1$ unit of the enzyme was incubated at $37^{\circ} \mathrm{C}$ for $10 \mathrm{~min}$, and the reaction was terminated by the addition of $2 \mathrm{ml}$ of an acidic $\mathrm{FeCl}_{3}$ solution $\left(10 \% \mathrm{FeCl}_{3}: 24 \%\right.$ TCA: $6 \mathrm{~N} \mathrm{HCl}$ : $\left.\mathrm{H}_{2} \mathrm{O}=8: 2: 1: 13\right) . \gamma$-Glutamylhydroxamate formed was determined colorimetrically at $540 \mathrm{~nm}$. (2) Biosynthetic reaction: a mixture $(1.0 \mathrm{ml})$ containing $100 \mathrm{~mm}$ imidazole$\mathrm{HCl}$ buffer ( $\mathrm{pH} 6.5$ for the B. bifidum a enzyme, and $\mathrm{pH}$ 6.0 for the $B$. breve 203 and $B$. pseudolongum a enzymes), $50 \mathrm{~mm}$ L-glutamate, $25 \mathrm{~mm} \mathrm{NH}_{4} \mathrm{Cl}, 7.5 \mathrm{~mm}$ ATP, $30 \mathrm{~mm}$ $\mathrm{MgCl}_{2}$ and $1 \sim 4$ units of the enzyme was incubated at $37^{\circ} \mathrm{C}$ for $10 \sim 30 \mathrm{~min}$. The reaction was terminated by the addition of $1 \mathrm{ml}$ of $3 \mathrm{~N} \mathrm{H}_{2} \mathrm{SO}_{4}$ and then the inorganic phosphate liberated was determined by the method of Fiske and Subbarow. ${ }^{28}$ (3) Synthetic reaction: a mixture $(1.0 \mathrm{ml})$ containing $100 \mathrm{~mm}$ acetate buffer $(\mathrm{pH} 5.5), 50 \mathrm{~mm}$ L-glutamate, $25 \mathrm{~mm}$ hydroxylamine- $\mathrm{HCl}, 7.5 \mathrm{~mm} \mathrm{ATP}$, $30 \mathrm{mM} \mathrm{MgCl}$ and about 1 unit of the enzyme was incubated at $37^{\circ} \mathrm{C}$ for $30 \mathrm{~min}$. The reaction was terminated and the product determined by the same procedures as for the transferring reaction.

One unit of enzyme activity was defined as the amount of enzyme forming $1 \mu \mathrm{mol}$ of $\gamma$-glutamylhydroxamate per $10 \mathrm{~min}$ in the transferring reaction. Specific activity was expressed as units per mg protein.

Protein was determined by the method of Lowry et al. ${ }^{29)}$ with egg albumin as a standard. It was also determined from the absorbance at $280 \mathrm{~nm}$ of eluates obtained on column chromatography.

Purification of glutamine synthetases. All procedures were carried out at $0 \sim 15^{\circ} \mathrm{C}$.

Step 1. Preparation of a cell-free extract: cells of $B$. bifidum a (about $800 \mathrm{~g}$ wet weight) from 300 liters of culture broth were suspended in $0.3 \mathrm{M}$ acetate buffer $(\mathrm{pH}$ 6.5) containing $20 \mathrm{~mm}$ EDTA and then disrupted with a Kaijo Denki ultrasonic oscillator $\left(20 \mathrm{kHz}\right.$, at $0 \sim 15^{\circ} \mathrm{C}$ for $1 \mathrm{hr}$ ). The cell debris was centrifuged off at $12,000 \times g$ for $30 \mathrm{~min}$, and the supernatant was dialyzed at $5^{\circ} \mathrm{C}$ for $48 \mathrm{hr}$ against $0.05 \mathrm{M}$ acetate buffer $(\mathrm{pH} 6.5)$ containing $3 \mathrm{~mm}$ EDTA. The crude extract was used as the starting material for the enzyme purification.

Step 2. Ammonium sulfate fractionation: the extract was fractionated with ammonium sulfate at $\mathrm{pH}$ 6.0. The fraction ( $45 \sim 60 \%$ saturation) in $0.05 \mathrm{~m}$ acetate buffer ( $\mathrm{pH}$ 6.0) was dialyzed against the same buffer.

Step 3. 1st DEAE-cellulose column chromatography: the dialyzed solution was applied to a DEAE-cellulose column $(5.4 \times 42 \mathrm{~cm})$ equilibrated with $0.05 \mathrm{M}$ acetate buffer ( $\mathrm{pH}$ 6.0). The column was developed by increasing the $\mathrm{NaCl}$ concentration stepwise in the buffer, and the enzyme was eluted with the buffer containing $0.3 \mathrm{~m} \mathrm{NaCl}$. The active fractions were concentrated by the addition of ammonium sulfate ( $80 \%$ saturation). The precipitate was dissolved in and then dialyzed against $0.05 \mathrm{M}$ acetate buffer (pH 6.0).

Step 4. 2nd DEAE-cellulose column chromatography: the dialyzed enzyme solution was applied to a DEAEcellulose column $(2.2 \times 25 \mathrm{~cm})$ equilibrated with $0.05 \mathrm{M}$ acetate buffer ( $\mathrm{pH}$ 6.0). Elution was performed by increasing the $\mathrm{NaCl}$ concentration linearly from 0.15 to $0.5 \mathrm{M}$. The enzyme was eluted at a $\mathrm{NaCl}$ concentration of about $0.3 \mathrm{M}$, and the active fractions were precipitated by the addition of ammonium sulfate ( $80 \%$ saturation).

Step 5. 1st Sepharose 6B column chromatography: the precipitate dissolved in a small volume of $0.05 \mathrm{M}$ acetate buffer ( $\mathrm{pH} 5.5)$ was filtered through a Sepharose 6B column $(3.2 \times 110 \mathrm{~cm})$ equilibrated with the same buffer. The active fractions were pooled and then concentrated with ammonium sulfate ( $80 \%$ saturation).

Step 6. 2nd Sepharose 6B column chromatography: the precipitate obtained was dissolved in $0.05 \mathrm{M}$ acetate buffer and then filtered through the same column as in step 5 . The active fractions were concentrated with ammonium sulfate $(80 \%$ saturation).

Step 7. Hydroxylapatite column chromatography: the concentrated enzyme solution was dialyzed against $0.05 \mathrm{M}$ acetate buffer ( $\mathrm{pH} \mathrm{5.5)}$ and then applied to a hydroxylapatite column $(1.65 \times 4 \mathrm{~cm})$ equilibrated with the same buffer. After washing the column with $1 \mathrm{~m}$ acetate buffer (pH 5.5) containing $1 \mathrm{M} \mathrm{NaCl}$, the enzyme was eluted with 0.05 м pyrophosphate buffer (pH 5.5).

The glutamine synthetases of $B$. breve 203 and $B$. pseudolongum a were purified by a similar procedure to that for the $B$. bifidum a enzyme with a slight modification: the acetate buffer ( $\mathrm{pH} 5.5,6.0$ or 6.5$)$ used for the B. bifidum a enzyme was replaced by imidazole- $\mathrm{HCl}$ buffer ( $\mathrm{pH}$ 6.0) except for in the hydroxylapatite column chromatography step. 
Gel electrophoresis. Disc gel electrophoresis of the enzymes was carried out at 5.0 or $7.5 \%$ gel concentration according to the procedure of Davis. ${ }^{30)}$

Chemicals. DEAE-cellulose and ATP were purchased from Sigma Chemicals Co. and Sepharose 6B from Pharmacia Fine Chemicals. Hydroxylapatite was prepared by the method of Tiselius et al. ${ }^{31)}$ Other chemicals were analytical grade commercial reagents.

\section{RESULTS}

\section{Purification}

The glutamine synthetases of $B$. bifidum a, $B$. breve 203 and B. pseudolongum a were purified 570-, 220- and 80-fold with 12, 5 and $0.5 \%$ yields, respectively (Table I). As shown in Fig. 1, each preparation gave a single protein band on polyacrylamide gel electrophoresis, but a slight impurity was observed in the $B$. bifidum a enzyme preparation.

Table I. Purification of Glutamine Synthetases FROM BIFIDOBACTERIA

\begin{tabular}{|c|c|c|c|}
\hline Preparation & $\begin{array}{l}\text { Protein } \\
(\mathrm{mg})\end{array}$ & $\begin{array}{c}\text { Specific } \\
\text { activity } \\
\text { (units/mg) }\end{array}$ & $\begin{array}{c}\text { Total } \\
\text { activity } \\
\text { (units) }\end{array}$ \\
\hline \multicolumn{4}{|l|}{ A) B. bifidum a } \\
\hline Cell-free extract & 29,700 & 3.9 & 115,500 \\
\hline $\begin{array}{l}\text { Ammonium sulfate } \\
\quad(45 \sim 60 \%)\end{array}$ & 9,370 & 9.9 & 92,800 \\
\hline 1st DEAE-cellulose & 720 & 93.4 & 67,400 \\
\hline 2nd DEAE-cellulose & 88 & 439 & 38,700 \\
\hline 1st Sepharose 6B & 34 & 1085 & 36,700 \\
\hline 2nd Sepharose 6B & 14 & 1527 & 21,100 \\
\hline Hydroxylapatite & 6 & 2213 & 13,300 \\
\hline \multicolumn{4}{|l|}{ B) B. breve 203} \\
\hline Cell-free extract & 53,000 & 3.3 & 175,000 \\
\hline $\begin{array}{l}\text { Ammonium sulfate } \\
\quad(45 \sim 70 \%)\end{array}$ & 19,500 & 8.3 & 162,000 \\
\hline DEAE-cellulose & 5,600 & 27.5 & 154,000 \\
\hline 1st Sepharose 6B & 1,600 & 53.1 & 85,000 \\
\hline Hydroxylapatite & 217 & 341 & 75,000 \\
\hline 2nd Sepharose 6B & 11 & 732 & 8,100 \\
\hline \multicolumn{4}{|l|}{ C) B. pseudolongum a } \\
\hline Cell-free extract & 44,200 & 13.2 & 583,000 \\
\hline $\begin{array}{l}\text { Ammonium sulfate } \\
\quad(45 \sim 60 \%)\end{array}$ & 7,850 & 64,6 & 507,000 \\
\hline DEAE-cellulose & 464 & 198 & 91,000 \\
\hline 1st Sepharose 6B & 309 & 219 & 67,000 \\
\hline 2nd Sepharose 6B & 23 & 739 & 17.000 \\
\hline Hydroxylapatite & 3 & 996 & 2,690 \\
\hline
\end{tabular}

\section{Molecular weight}

The molecular weights of the enzymes were determined to be about 500,000 by gel filtration on Sepharose 6B with catalase (molecular weight, 230,000), glutamate dehydrogenase $(350,000)$, apoferritin $(480,000)$ and thyroglobulin $(669,000)$ as standard proteins.

\section{Substrate specificity and effects of divalent cations}

Table II summarizes the specificities of the enzymes toward substrates and divalent cations in their biosynthetic reactions. The bifidobacterial enzymes were specific for Lglutamate as an amino acid. Hydroxylamine could be substituted for ammonia: the $B$. bifidum a, B. breve 203 and $B$. pseudolongum a enzymes showed 59, 13 and $10 \%$ reactivity toward ammonia, respectively. Methylamine and ethylamine were slightly effective. ATP was replaceable by GTP in the reaction with the $B$. bifidum a enzyme $(15 \%$ reactivity) but not in the reactions with the $B$. breve 203 and

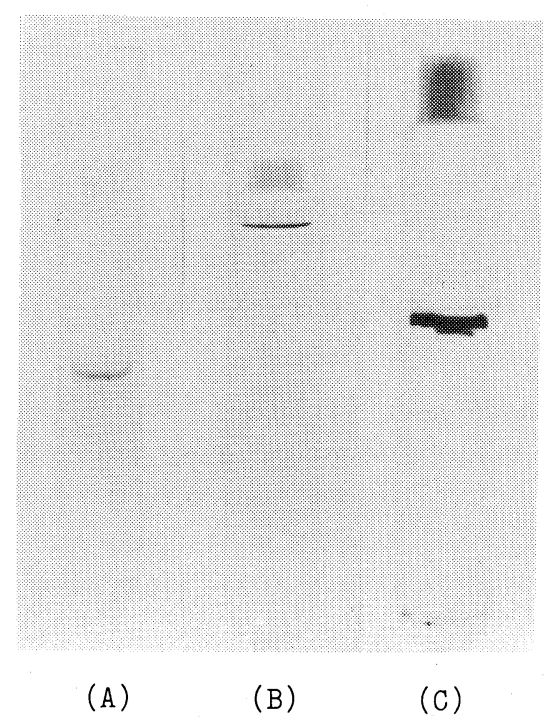

FIG. 1. Disc Gel Electrophoresis of Glutamine Synthetases from B. bifidum a, B. breve 203 and $B$. pseudolongum a.

The enzyme preparations were electrophoresed on polyacrylamide gel at a current of $2 \mathrm{~mA}$ for $90 \mathrm{~min}$ at $\mathrm{pH} 8.9$.

(A) B. bifidum a enzyme (10 $\mu \mathrm{g}$ protein on $5 \% \mathrm{gel})$.

(B) B. breve 203 enzyme (10 $\mu \mathrm{g}$ protein on $7.5 \% \mathrm{gel})$.

(C) B. pseudolongum a enzyme (30 $\mu$ g protein on $5 \%$ gel). 


\section{Table II. Substrate and Divalent Cation Specificities of Glutamine Synthetases}

Substrate analogues were substituted for usual substrates at their concentrations in the biosynthetic reaction mixture. In the divalent cation specificity experiment, $30 \mathrm{~mm} \mathrm{Mg}{ }^{2+}$ was replaced by divalent cations at concentrations of 3 and $30 \mathrm{~mm}$. Inorganic phosphate was determined.

\begin{tabular}{|c|c|c|c|}
\hline \multirow{2}{*}{$\begin{array}{l}\text { Substrate and } \\
\text { divalent cation }\end{array}$} & \multicolumn{3}{|c|}{$\begin{array}{l}\text { Relative activity }(\%) \text { of } \\
\text { glutamine synthetase from }\end{array}$} \\
\hline & B. bifidum a & B. breve 203 & B. pseudolongum a \\
\hline L-Glutamate & 100 & 100 & 100 \\
\hline D-Glutamate & 0 & 0 & 0 \\
\hline L-Aspartate & 0 & 0 & 0 \\
\hline D-Aspartate & 0 & 0 & 0 \\
\hline DL- $\alpha$-Aminoadipate ${ }^{a}$ & 0 & 0 & 0 \\
\hline DL- $\alpha$-Aminopimelate ${ }^{a}$ & 0 & 0 & 0 \\
\hline Ammonia & 100 & 100 & 100 \\
\hline Hydroxylamine & 59 & 13 & 10 \\
\hline Methylamine & 5 & 4 & 3 \\
\hline Ethylamine & 2 & 4 & 3 \\
\hline ATP & 100 & 100 & 100 \\
\hline GTP & 15 & 0 & 0 \\
\hline UTP & 3 & 4 & 0 \\
\hline CTP & 2 & 0 & 0 \\
\hline ADP & 2 & 0 & 0 \\
\hline AMP & 0 & 0 & 0 \\
\hline \multicolumn{4}{|l|}{ Cations } \\
\hline $\mathrm{Mg}^{2+}(30 \mathrm{~mm})$ & 100 & 100 & 100 \\
\hline$(3 \mathrm{~mm})$ & 14 & 4 & 10 \\
\hline $\mathrm{Mn}^{2+}(30 \mathrm{mM})$ & 250 & 156 & 160 \\
\hline$(3 \mathrm{~mm})$ & 216 & 201 & 190 \\
\hline $\mathrm{Co}^{2+}(30 \mathrm{~mm})$ & 19 & 6 & 14 \\
\hline$(3 \mathrm{~mm})$ & 11 & 4 & 11 \\
\hline Others $^{b}(30 \mathrm{~mm})$ & 0 & 0 & 0 \\
\hline
\end{tabular}

B. pseudolongum a enzymes.

The bifidobacterial enzymes required $\mathrm{Mg}^{2+}$, $\mathrm{Mn}^{2+}$ or $\mathrm{Co}^{2+}$ for their biosynthetic reactions, of which $\mathrm{Mn}^{2+}$ was the most effective, as is the case for the enzymes from some other bacteria. ${ }^{15,16,32)}$

The relationship between enzyme activity and the concentration of $\mathrm{Mg}^{2+}, \mathrm{Mn}^{2+}$ or $\mathrm{Co}^{2+}$ was investigated in mixtures containing various concentrations of ATP (Fig. 2). For $\mathrm{Mg}^{2+}$, the activities of the three enzymes were maximal when $\mathrm{Mg}^{2+}$ was in excess of ATP. The activities of the $B$. breve 203 and $B$. pseudolongum a enzymes were inhibited by a higher concentration of ATP. The same phenomenon was found with $\mathrm{Mn}^{2+}$ and $\mathrm{Co}^{2+}$

The activity with $\mathrm{Mn}^{2+}$ was generally maximal when the ratio of ATP to $\mathrm{Mn}^{2+}$ was 1.0 , and decreased with deviation from this ratio. The decrease at a higher concentration of $\mathrm{Mn}^{2+}$, however, was less remarkable than in the case of the enzyme from gram-positive Bacillus subtilis. ${ }^{33)}$

The effect of $\mathrm{Co}^{2+}$ varied with the enzyme source. The maximum activity of the $B . b i$ fidum a enzyme was seen when $\mathrm{Co}^{2+}$ was in excess of ATP while those of the B. breve 203 and $B$. pseudolongum a enzymes were seen at the ATP- $\mathrm{Co}^{2+}$ ratio of 1.0 . 
Table III. Enhancement by $\mathrm{Co}^{2+}$ of Glutamine Synthetase Activity in the Reaction Mixture with a Suboptimal Concentration of $\mathrm{Mg}^{2+}$

The activity in the biosynthetic reaction was assayed in the presence of the metals shown in the table. The activity was expressed as a percentage of that with $4 \mathrm{mM} \cdot \mathrm{Mg}^{2+}$ alone. The buffers used were $100 \mathrm{~mm}$ imidazole- $\mathrm{HCl}$ buffer ( $\mathrm{pH}$ 6.5) for the B. bifidum a enzyme and $100 \mathrm{~mm}$ imidazole- $\mathrm{HCl}$ buffer ( $\mathrm{pH} 6.0$ ) for the $B$. breve 203 and $B$. pseudolongum a enzymes.

\begin{tabular}{cccc}
\hline & & \multicolumn{2}{c}{$\begin{array}{c}\text { Relative activity }(\%) \text { of } \\
\text { glutamine synthetase from }\end{array}$} \\
\cline { 2 - 4 } & B. bifidum a & B. breve 203 & B. pseudolongum a \\
\hline $4 \mathrm{mM} \mathrm{MgCl}_{2}$ & 100 & 100 & 100 \\
$4 \mathrm{mM} \mathrm{MgCl}_{2}+3 \mathrm{mM} \mathrm{CoCl}_{2}$ & 535 & 326 & 657 \\
$4 \mathrm{mM} \mathrm{MgCl}_{2}+3 \mathrm{mM} \mathrm{MgCl}_{2}$ & 226 & 281 & 293 \\
$3 \mathrm{mM} \mathrm{CoCl}_{2}$ & 100 & 36 & 49 \\
$7 \mathrm{mM} \mathrm{CoCl}_{2}$ & 185 & 93 & 114 \\
\hline
\end{tabular}

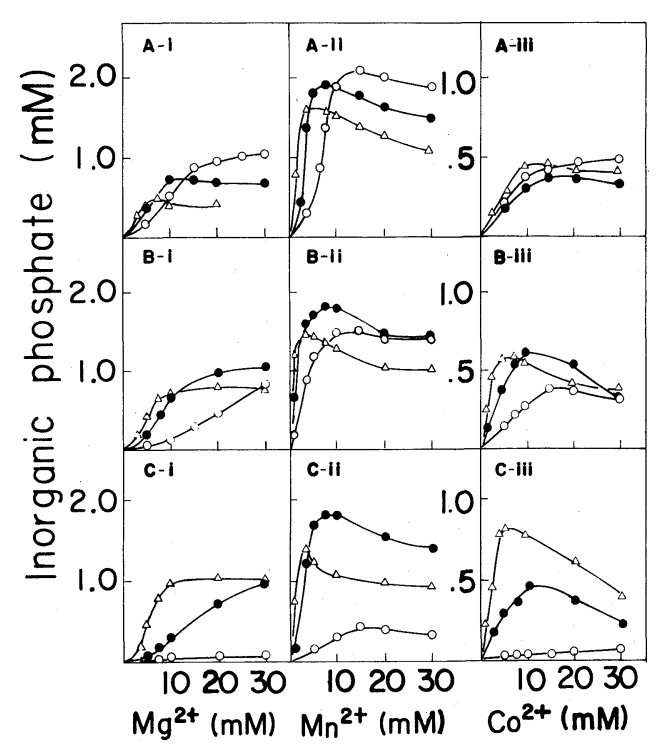

FIG. 2. Effects of the Concentrations of ATP and Divalent Cations on the Activity of Glutamine Synthetases from (A) B. bifidum a, (B) B. breve 203 and (C) B. pseudolongum a.

The concentrations of ATP and (i) $\mathrm{Mg}^{2+}$, (ii) $\mathrm{Mn}^{2+}$ or (iii) $\mathrm{Co}^{2+}$ in the biosynthetic mixture were varied as shown in the figure. The enzyme activity is expressed as inorganic phosphate (mM) liberated. Symbols: $\triangle-\triangle$, ATP $3.75 \mathrm{~mm}$; - - ATP $7.5 \mathrm{~mm}$; ○一

\section{Stimulation of enzyme activity by $\mathrm{Co}^{2+}$}

The activity of the bifidobacterial glutamine synthetases under $\mathrm{Mg}^{2+}$-unsaturated conditions was remarkably enhanced by the addition of a small amount of $\mathrm{Co}^{2+}$, as was
Table IV. Optimum pH of Glutamine SYNTHETASE REACTIONS

The activities of the transferring, synthetic and biosynthetic reactions were assayed under the conditions given under Materials and Methods. In the biosynthetic reaction, $30 \mathrm{~mm} \mathrm{Mg}^{2+}$ was replaced with $7.5 \mathrm{~mm} \mathrm{Mn^{2+ }}$ or $30 \mathrm{~mm} \mathrm{Co}^{2+}$. The buffers used were $100 \mathrm{~mm}$ acetate buffer $(\mathrm{pH} 4.0 \sim 6.5)$ and $100 \mathrm{~mm}$ imidazole- $\mathrm{HCl}$ buffer $(\mathrm{pH}$ $5.5 \sim 8.0)$.

\begin{tabular}{|c|c|c|c|}
\hline \multirow{2}{*}{ Reaction } & \multicolumn{3}{|c|}{$\begin{array}{l}\text { Optimum pH of glutamine } \\
\text { synthetase from }\end{array}$} \\
\hline & $\begin{array}{l}B . \\
\text { bifidum a }\end{array}$ & $\begin{array}{l}\text { B. } \\
\text { breve } 203\end{array}$ & $\begin{array}{l}B . \\
\text { pseudolongum a }\end{array}$ \\
\hline $\begin{array}{l}\text { Transferring } \\
\text { reaction }\end{array}$ & 6.5 & 6.5 & 6.5 \\
\hline $\begin{array}{l}\text { Synthetic } \\
\text { reaction }\end{array}$ & 5.5 & 6.5 & 6.0 \\
\hline \multicolumn{4}{|l|}{$\begin{array}{l}\text { Biosynthetic } \\
\text { reaction }\end{array}$} \\
\hline $\mathrm{Mg}^{2+}(30 \mathrm{mM})$ & 6.5 & 6.0 & 6.0 \\
\hline $\mathrm{Mn}^{2+}(7.5 \mathrm{mM})$ & 5.5 & 5.5 & 5.5 \\
\hline $\mathrm{Co}^{2+}(30 \mathrm{~mm})$ & 6.5 & 6.5 & 6.5 \\
\hline
\end{tabular}

observed with the Escherichia coli enzyme ${ }^{34)}$ (Table III). The addition of $3 \mathrm{mM} \mathrm{Co}^{2+}$ to biosynthetic reaction mixtures containing $4 \mathrm{mM} \mathrm{Mg}^{2+}$ resulted in a 3-7-fold increase in the activity. The stimulation was not due to the increase in ionic strength.

\section{Effect of $\mathrm{pH}$ on the enzymes}

As shown in Table IV, the reactions of the 
bifidobacterial glutamine synthetases proceeded optimally in the acidic $\mathrm{pH}$ range of $5.5 \sim 6.5$. It was noticeable that the $\mathrm{pH}$ optimum varied with the divalent cation in the mixture.

The enzymes were most stable at $\mathrm{pH}$ $5.0 \sim 6.0$ : the $B$. bifidum a enzyme retained $86 \%$ of its initial activity after incubation in $0.1 \mathrm{M}$ acetate buffer ( $\mathrm{pH} 5.5)$ for $10 \mathrm{~min}$ at $60^{\circ} \mathrm{C}$, and the $B$. breve 203 and $B$. pseudolongum a enzymes retained, respectively, $50 \%$ and $42 \%$ in
$0.1 \mathrm{M}$ imidazole- $\mathrm{HCl}$ buffer $(\mathrm{pH} 6.0)$.

\section{Km values}

As summarized in Table V, the $K m$ values of the enzymes for L-glutamate, ammonia and ATP in the biosynthetic reactions with $\mathrm{Mg}^{2+}$ and $\mathrm{Mn}^{2+}$ were mostly the same. It was of interest that the bifidobacterial enzymes showed lower $\mathrm{Km}$ values for ammonia than the enzymes from other bacteria, ${ }^{17,18,32,35)}$ and that the value for L-glutamate decreased

Table V. $K m$ Values for Substrates of Glutamine Synthetases With $\mathrm{Mg}^{2+}$ OR $\mathrm{Mn}^{2+}$ AS THE Divalent CATION

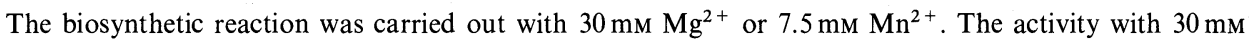
$\mathrm{Mg}^{2+}$ was assayed at $\mathrm{pH}$ 6.5, 6.0 and 6.0 with $100 \mathrm{~mm}$ imidazole- $\mathrm{HCl}$ buffer for the B. bifidum a, B. breve 203 and $B$. pseudolongum a enzymes, respectively. The activity with $7.5 \mathrm{mM} \mathrm{Mn}^{2+}$ was assayed with $100 \mathrm{~mm}$ acetate buffer (pH 5.5). Inorganic phosphate liberated was determined.

$K m(\mathrm{~mm})$ values of glutamine synthetase from

\begin{tabular}{|c|c|c|c|c|c|c|}
\hline \multirow[t]{2}{*}{ Substrate } & \multicolumn{2}{|c|}{ B. bifidum a } & \multicolumn{2}{|c|}{ B. breve 203} & \multicolumn{2}{|c|}{ B. pseudolongum a } \\
\hline & $\mathrm{Mg}^{2+}$ & $\mathrm{Mn}^{2+}$ & $\mathrm{Mg}^{2+}$ & $\mathrm{Mn}^{2+}$ & $\mathrm{Mg}^{2+}$ & $\mathrm{Mn}^{2+}$ \\
\hline L-Glutamate & 25 & 1.1 & 21 & 1.3 & 18 & 2.1 \\
\hline Ammonia & 0.56 & 0.77 & 0.59 & 0.69 & 0.69 & 0.71 \\
\hline ATP & 2.0 & 2.0 & 1.7 & 2.3 & 1.5 & 2.5 \\
\hline
\end{tabular}

Table VI. Effects of Some Metabolites on Glutamine Synthetase Activity

The enzyme activity was determined with the mixture for the biosynthetic reaction in the presence of $30 \mathrm{~mm}$ $\mathrm{Mg}^{2+}$ or $7.5 \mathrm{~mm} \mathrm{Mn}^{2+}$. The substances were added to the mixture at the concentration of $8 \mathrm{~mm}$. Other conditions were the same as in Table V. Inorganic phosphate was determined.

\begin{tabular}{|c|c|c|c|c|c|c|}
\hline \multirow{3}{*}{$\begin{array}{l}\text { Addition } \\
(8 \mathrm{~mm})\end{array}$} & \multicolumn{6}{|c|}{ Relative activity $(\%)$ of glutamine synthetase from } \\
\hline & \multicolumn{2}{|c|}{ B. bifidum a } & \multicolumn{2}{|c|}{ B. breve 203} & \multicolumn{2}{|c|}{ B. pseudolongum a } \\
\hline & $\mathrm{Mg}^{2+}$ & $\mathrm{Mn}^{2+}$ & $\mathrm{Mg}^{2+}$ & $\mathrm{Mn}^{2+}$ & $\mathrm{Mg}^{2+}$ & $\mathrm{Mn}^{2+}$ \\
\hline None & 100 & 100 & 100 & 100 & 100 & 100 \\
\hline Glycine & 98 & 75 & 100 & 68 & 78 & 59 \\
\hline L-Alanine & 94 & 63 & 96 & 61 & 83 & 35 \\
\hline L-Threonine & 100 & 96 & 100 & 100 & 91 & 82 \\
\hline L-Histidine & 100 & 94 & 99 & 99 & 89 & 89 \\
\hline L-Tryptophan & 99 & 97 & 100 & 98 & 100 & 100 \\
\hline L-Glutamine & 98 & 91 & 100 & 96 & 74 & 91 \\
\hline $\mathrm{ADP}$ & 38 & 57 & 18 & 57 & 23 & 48 \\
\hline AMP & 83 & 99 & 40 & 83 & 56 & 51 \\
\hline Adenosine & 10 & 73 & 7 & 56 & 19 & 45 \\
\hline CMP & 100 & 98 & 100 & 92 & 82 & 65 \\
\hline GMP & - & - & 93 & 82 & 94 & 64 \\
\hline
\end{tabular}


Table VII. Effects of Heavy Metals on Glutamine Synthetase Activity

The metals were added at a concentration of $5 \mathrm{~mm}$ to the biosynthetic reaction mixture containing $30 \mathrm{~mm}$ $\mathrm{Mg}^{2+}$ or $7.5 \mathrm{~mm} \mathrm{Mn}^{2+}$. Other conditions were the same as in Table $\mathrm{V}$.

\begin{tabular}{|c|c|c|c|c|}
\hline \multirow{3}{*}{$\begin{array}{l}\text { Metal } \\
(5 \mathrm{~mm})\end{array}$} & \multicolumn{4}{|c|}{$\begin{array}{l}\text { Relative activity }(\%) \text { of } \\
\text { glutamine synthetase from }\end{array}$} \\
\hline & \multicolumn{2}{|c|}{ B. bifidum a } & \multicolumn{2}{|c|}{ B. pseudolongum a } \\
\hline & $\mathrm{Mg}^{2+}$ & $\mathrm{Mn}^{2+}$ & $\mathrm{Mg}^{2+}$ & $\mathrm{Mn}^{2+}$ \\
\hline None & 100 & 100 & 100 & 100 \\
\hline $\mathrm{Zn}^{2+}$ (sulfate) & 71 & 30 & 23 & 59 \\
\hline $\mathrm{Ca}^{2+}$ (chloride) & 56 & 35 & 33 & 92 \\
\hline $\mathrm{Cu}^{2+}$ (chloride) & 26 & 61 & 15 & 55 \\
\hline $\mathrm{NI}^{2+}$ (sulfate) & 23 & 27 & 13 & 90 \\
\hline $\mathrm{Fe}^{2+}$ (sulfate) & 15 & 16 & 32 & 37 \\
\hline $\mathrm{Hg}^{2+}$ (chloride) & 3 & 70 & 44 & 86 \\
\hline $\mathrm{Pb}^{2+}$ (acetate) & 2 & 16 & - & - \\
\hline
\end{tabular}

strikingly when $7.5 \mathrm{~mm} \mathrm{Mn}^{2+}$ was substituted for $30 \mathrm{~mm} \mathrm{Mg}^{2+}$.

\section{Effects of some metabolites and heavy metals}

The susceptibility of the bifidobacterial glutamine synthetases to some metabolites also varied with the divalent cation (Table VI). Like in the case of the Bacillus subtilis enzyme, ${ }^{36)}$ their activities were more inhibited by L-alanine and glycine in the mixture with $\mathrm{Mn}^{2+}$ than with $\mathrm{Mg}^{2+}$, while ADP, AMP and adenosine were more potent inhibitors in the reactions with $\mathrm{Mg}^{2+}$ than with $\mathrm{Mn}^{2+}$. These findings suggested that the activities might be controlled by feedback inhibition and the energy charge according to the divalent cation present.

The effects of heavy metals on the enzyme activity also differed with $\mathrm{Mg}^{2+}$ and $\mathrm{Mn}^{2+}$ in the mixture (Table VII).

\section{DISCUSSION}

Bifidobacteria are the predominant bacteria in the intestine of humans and some animals, and are supposed to be beneficial as to the host's health because they reduce putrefactive bacteria and their metabolites. ${ }^{37)}$ Biochemical information on the metabolic activity of nitrogenous compounds might be valuable for consideration of the function of the organisms in the intestine. A preliminary experiment ${ }^{10)}$ on their glutamine synthetases and glutamate dehydrogenases suggested that these enzymes might participate in ammonia assimilation by these organisms. The present work was undertaken on glutamine synthetase to clarify its role in ammonia assimilation.

The glutamine synthetases from $B$. bifidum a, B. breve 203 and $B$. pseudolongum a were similar in many properties, such as molecular weight, specificity and $K m$ values for substrates, optimum $\mathrm{pH}$, requirement for divalent cations and susceptibility to metabolites, but showed a few differences in the reactivity to GTP (Table II), the effect of $\mathrm{Co}^{2+}$ and inhibition by an excess of ATP (Fig. 2). Therefore, it seems that the enzymes of these Bifidobacterium species are essentially not different.

Bifidobacterial glutamine synthetases show several characteristic properties compared with other bacterial enzymes. Firstly, as shown in Table IV, they reacted optimally in the acidic $\mathrm{pH}$ range of $6.0 \sim 6.5$ for the biosynthetic reaction with $30 \mathrm{~mm} \mathrm{Mg}^{2+}$, while the enzymes of other bacteria mostly have neutral and alkaline $\mathrm{pH}$ optima (e.g., $\mathrm{pH} 7.7$ for the Escherichia coli enzyme, ${ }^{35)} \mathrm{pH} 7.2$ for the Bacillus subtilis enzyme, ${ }^{33)} \mathrm{pH} 7 \sim 8$ for the Micrococcus glutamicus enzyme, ${ }^{18)}$ and $\mathrm{pH} 8.5$ for the Gluconobacter suboxydans enzyme ${ }^{17)}$ ). Secondly, the bifidobacterial enzymes showed lower $\mathrm{Km}$ values for ammonia than the enzymes of many other bacteria. ${ }^{17,18,32,35)}$ This suggests that they might play a role in the ammonia assimilation by bifidobacteria, which form acetic acid and lactic acid during their growth. Thirdly, their affinity for L-glutamate increased by more than 10 -fold (Table V), and their reactivity was enhanced (Table II) when $\mathrm{Mn}^{2+}$ was substituted for $\mathrm{Mg}^{2+}$, indicating that $\mathrm{Mn}^{2+}$ might play a significant role in the reactions of the bifidobacterial enzymes.

As mentioned above, glutamine synthetases are known to be regulated in enteric bacteria 
by a complex of five mechanisms. The present results indicate the possible regulation of bifidobacterial enzymes by divalent cations. The variation of the enzyme activity with the type and concentration of divalent cation in the reaction mixture (Fig. 2) and the activating effect of $\mathrm{Co}^{2+}$ with a suboptimal level of $\mathrm{Mg}^{2+}$ (Table III) were similar to those observed with the glutamine synthetases from Escherichia coli $^{34)}$ and other bacteria, ${ }^{17,21)}$ which are regulated by divalent cations. Furthermore, the changes in such enzymatic properties as optimum $\mathrm{pH}$ (Table IV), $K m$ value for L-glutamate (Table V) and susceptibility to some metabolites (Table VI) indicated the role of divalent cations in the regulation. The differences in the inhibitory effects of several heavy metals, depending on whether $\mathrm{Mg}^{2+}$ or $\mathrm{Mn}^{2+}$ was present in the reaction mixture (Table VII), might imply a conformational change caused by the divalent cation, as observed for enzymes from other sources. $^{38,39)}$

The results in Table VI at the same time suggest that the enzyme activity might be controlled by feedback inhibition and by the energy charge in the organisms.

Variation of the glutamine synthetase level in the cells in response to the nitrogen source in the culture medium (i.e., the regulatory system of repression-derepression of the enzyme formation) and the adenylylationdeadenylylation system of the enzyme protein, which has been recognized in gram-negative bacteria and found recently in gram-positive Streptomyces $^{40)}$ and Mycobacterium, ${ }^{41)}$ were not investigated in this study due to the complex nutritional requirements of bifidobacteria. The recent establishment of a defined minimum medium for B. bifidum Es $5^{42)}$ might make it possible to examine them.

In parallel with this study, we are working on the purification and characterization of the glutamate dehydrogenases from the same organisms. This enzyme is assumed to participate in the incorporation of ammonia together with glutamine synthetase. ${ }^{10)}$ Comparative discussion as to glutamine synthe- tase and glutamate dehydrogenase will reveal the mechanism of ammonia assimilation by bifidobacteria.

\section{REFERENCES}

1) M. H. Tisser, C. R. Soc. Biol., 51, 943 (1899).

2) T. Mitsuoka and C. Kaneuchi, Am. J. Clin. Nutr., 30, 1799 (1977).

3) A. Watanabe and Y. Mutai, Jpn. J. Pediatricus, 28, 19 (1975).

4) W. Fujiwara, N. Takao, S. Motoyama and K. Tanaka, Kachiku Shinryo, 171, 19 (1977).

5) A. Kobayashi, Feed and Feed Industry, 18, 37 (1978).

6) L. Lee, A. Kimura and T. Tochikura, J. Ferment. Technol., 55, 19 (1977).

7) L. Lee, A. Kimura and T. Tochikura, J. Ferment. Technol., 55, 130 (1977).

8) T. Tochikura, K. Sakai, T. Fujiyoshi, T. Tachiki and H. Kumagai, Agric. Biol. Chem., 50, 2279 (1986).

9) K. Sakai, T. Tachiki, H. Kumagai and T. Tochikura, Agric. Biol. Chem., 50, 2287 (1986).

10) M. Hatanaka, T. Tachiki, H. Kumagai and T. Tochikura, Agric. Biol. Chem., 51, 251 (1987).

11) C. M. Brown, D. S. MacDonald Brown and J. L. Meers, Adv. Micro. Physiol., 11, 1 (1974).

12) B. M. Shapiro and E. R. Stadtman, Ann. Rev. Microbiol., 24, 501 (1970).

13) R. A. Bender, A. K. Janssen, A. D. Resnik, M. Blumenberg, F. Foor and B. Magasanik, $J$. Bacteriol., 129, 1001 (1977).

14) J. Siedel and E. Shelton, Arch. Biochem. Biophys., 192, 214 (1979).

15) S. L. Streicher and B. Tyler, J. Bacteriol., 93, 1045 (1980).

16) B. Bhandari and D. J. D. Nicholas, Aust. J. Biol. Sci., 34, 527 (1981).

17) T. Tachiki, K. Tokoro and T. Tochikura, J. Ferment. Technol., 61, 83 (1983).

18) T. Tachiki, S. Wakisaka, H. Kumagai and $T$. Tochikura, Agric. Biol. Chem., 45, 1487 (1981).

19) A. P. Mitchell and B. Magasanik, J. Biol. Chem., 258, 119 (1983).

20) S. K. Sawhney and D. J. D. Nicholas, Planta, 139, 289 (1978).

21) G. Stacey, C. V. Baalen and F. R. Tabita, Arch. Biochem. Biophys., 194, 457 (1979).

22) B. J. Miflin and P. J. Lea, Ann. Rev. Plant Physiol., 28, 299 (1977).

23) A. Meister, "The Enzymes," Vol. X, ed. by P. D. Boyer, Academic Press, New York and London, 1974, p. 699.

24) S. S. Tate and A. Meister, Proc. Natl. Acad. Sci. U.S.A., 68, 781 (1971).

25) E. R. Stadtman and A. Ginsburg, "The Enzymes," Vol. X, ed. by P. D. Boyer, Academic Press, New 
York and London, 1974, p. 755.

26) H. Holzer and W. Duntz, Ann. Rev. Biochem., 40, 345 (1971).

27) T. Mitsuoka, Rinsho Kensa, 18, 7 (1983).

28) C. H. Fiske and Y. Subbarow, J. Biol. Chem., 66, 375 (1925).

29) O. H. Lowry, N. J. Rosebrough, A. L. Farr and R. J. Randall, J. Biol. Chem., 126, 564 (1978).

30) B. J. Davis, Ann. N. Y. Acad. Sci., 121, 404 (1964 1966).

31) A. Tiselius, S. Hjerten and O. Levin, Arch. Biochem. Biophys., 65, 132 (1956).

32) J. M. Ravel, J. S. Humphrey and W. Shive, Arch. Biochem. Biophys., 111, 720 (1965).

33) T. F. Deuel and E. R. Stadtman, J. Biol. Chem., 245, 5206 (1970).

34) A. Segal and E. R. Stadtman, Arch. Biochem.
Biophys., 152, 367 (1972).

35) C. A. Woolfolk, B. Shapiro and E. R. Stadtman, Arch. Biochem. Biophys., 116, 177 (1966).

36) T. F. Deuel and D. Prusiner, J. Biol. Chem., 249, 257 (1974).

37) T. Mitsuoka, Bifidobacteria Microflora, 1, 3 (1982).

38) B. M. Shapiro and A. Ginsburg, Biochemistry, 7, 2153 (1968).

39) K. Matsuoka and K. Kimura, J. Biochem., 97, 1033 (1985).

40) S. L. Streicher and B. Tyler, Proc. Natl. Acad. Sci. U.S.A., 78, 229 (1981).

41) K. Kimura, K. Yagi and K. Matsuoka, J. Biochem., 95, 1599 (1984).

42) M. Ueda, S. Nakamoto, R. Nakai and A. Takagi, $J$. Gen. Appl. Microbiol., 29, 103 (1983). 